\title{
ANALISIS KUALITAS FISIKA KIMIA AIR HUJAN DI DESA DARAWA BERDASARKAN STANDAR KUALITAS AIR BERSIH DI KECAMATAN KALEDUPASELATAN KABUPATEN WAKATOBI
}

\author{
Dewi Yanti ${ }^{1}$, La Harudu ${ }^{2}$ \\ 1 Alumni Pendidikan Geografi FKIP UHO \\ 2 Dosen Pendidikan Geografi FKIP UHO
}

\begin{abstract}
Abstrak: Tujuan penelitian adalah untuk mengetahui kelayakan konsumsi air hujan di Desa Darawa berdasarkan Peraturan Menteri Kesehatan RI No. 492/Menkes/Per/IV/2010 tentang persyaratan kualitas air minum. Lokasi penelitian dilaksanakan di Desa Darawa Kecamatan Kaledupa Selatan, Kabupaten Wakatobi. Pengujian terhadap sampel air hujan yang diambil dari wadah penampungan warga di Desa Darawa pada parameter bau, warna, TDS, kekeruhan, ph, seng dan kandungan detergen dilakukan di BalaiLaboratorium Kesehatan Kendari. Berdasarkan hasil pemeriksaan sampel, baik yang dilakukan pada saat penelitian dilapangan maupun dari hasil pengujian sampel yang dikeluarkan oleh BalaiLaboratorium Kesehatan Kendari, menunjukkan bahwa dari semua parameter yang menjadi parameter penelitian baik pada parameter bau, warna, TDS, kekeruhan, rasa, suhu, $\mathrm{pH}$, seng serta kandungan deterjen memenuhi syarat dan layak untuk dikonsumsi berdasarkan Peraturan Menteri Kesehatan RI No 492/Per/IV/2010 tentang persyaratan kualitas air minum.
\end{abstract}

Kata Kunci: analisis,air hujan, kualitas, kelayakan. 


\title{
PHYSICAL CHEMICAL QUALITY ANALYSIS OF RAINWATER IN DARAWA VILLAGE BASED ON WATER QUALITY STANDARDS IN SOUTH KALEDUPA SUB-DISTRICT, WAKATOBI DISTRICT
}

\author{
Dewi Yanti ${ }^{1}$, La Harudu ${ }^{2}$ \\ 1 Alumnus Geography Education FKIP UHO \\ ${ }^{2}$ lecturer of geography education FKIP UHO
}

\begin{abstract}
The purpose of this research is to know the feasibility of rain water consumption in Darawa Village based on RI Minister of Health Regulation No. 492/Menkes/Per/IV/2010 regarding drinking water quality requirements. The research location was conducted in Darawa Village, South Kaledupa Subdistrict, Wakatobi Regency. Tests of rainwater samples taken from residents' shelters in Darawa Village on the odor, color, TDS, turbidity, ph, zinc and detergent parameters were performed at Kendari Health Laboratory Hall.Based on the results of the sample examination, whether conducted at the time of research in the field or from the test results of samples issued by Kendari Health Laboratory, showed that from all parameters which become the parameters of research both on the parameters of odor, color, TDS, turbidity, taste, temperature, $\mathrm{pH}$, zinc and detergent content are eligible and suitable for consumption based on Regulation of the Minister of Health No. 492/Per/I /2010 regarding drinking water quality requirements.
\end{abstract}

Keywords: analysis, rain water, quality, feasibility.

\section{PENDAHULUAN}

Air merupakan kebutuhan utama bagi makhluk hidup di muka bumi. air seringkali dianggap sebagai sumber daya alam yang tidak terbatas jumlahnya dan akan selalu ada setiap saat. namun demikian, air merupakan sumber daya alam yang terbatas ketersediaanya karena mempunyai siklus tata air yang relatif tetap. Pada dasarnya ketersediaan air di muka bumi menurut (Sugandy, 2007) tidak pernah bertambah dan tidak tersebar secara merata.

Air merupakan senyawa kimia yang sangat penting bagi kehidupan makhluk hidup di bumi ini. Fungsi air bagi kehidupan tidak dapat digantikan oleh senyawa lain. Penggunaan air yang utama dan sangat vital bagi kehidupan adalah sebagai air minum. Hal ini untuk memenuhi kebutuhan air dalam tubuh. Sekitar 55-60\% berat badan orang dewasa terdiri dari air, untuk anak-anak sekitar $65 \%$ dan untuk bayi sekitar $80 \%$ (Notoadmodjo, 2003).

Masalah Keterbatasan sumberdaya air dibeberapa daerah menimbulkan berbagai masalah yang serius bagi kesehatan penduduk yang bermukim di daerah tersebut. Sehingga ketersediaan dan pengelolaan air menjadi sangat penting untuk mendukung kehidupan masyarakat. Pengelolaan air bersih berdasarkan kualitas dan kuantitasnya akan mempengaruhi kualitas hidup penduduk, sehingga pemenuhan kebutuhan akan air bersih pada pemukiman menjadi sebuah hak masyarakat yang harus dipenuhi secara adil (Sanim, 2011). 
Berdasarkan keputusan Presiden RI No. 81 Tahun 2001 Tentang Komite Kebijakan Percepatan Pembangunan Infrastruktur, disebut dalam pasal 2, bahwa pembangunan infrastruktur mencakup prasarana dan sarana pengairan serta fasilitas umum yaitu jaringan listrik, telekomunikasi, dan jaringan pipa PAM. Pada standar pelayanan minimal (SPM) bidang air bersih bahwa kewajiban pemerintah berdasarkan target Millennium Development Goals (MDGs) adalah menyediakan air bersih secara kontinyu yang dapat diakses paling tidak oleh $68.87 \%$ penduduk.

\section{UNEP (United Nations}

Environment Programme) tahun 2011 menyarankan dengan mendasarkan pada meteorologi dan karakteristik geografis pemanenan air hujan, dimana curah hujan tahunan di Indonesia mencapai $2263 \mathrm{~mm}$ yang cenderung terdistribusi secara merata sepanjang tahun tanpa ada perbedaan yang mencolok antara musim hujan dan musim kemarau (Song et al., 2009). Oleh karena itu pemanenan air hujan di Indonesia perlu ditindaklanjuti sebagai salah satu upaya pengelolaan sumber daya air yang berkelanjutan.

Wilayah kepulauan umumnya memang bukanlah wilayahyangmemiliki curah hujan tinggi, namun mengenai banyaknya jumlah air hujan yang tertampung, tentu semua berkaitan dengan lokasi, luas area rumah, luas bak penampungan, dan curah hujan di sekitar rumah. Rata-rata setiap rumah tangga mampu menampung hingga 100.000 liter air hujan selama musim penghujan. Jumlah ini akan lebih banyak, terutama pada rumah - rumah besar, gedung, atau bangunan komersial beratap flat roof dan ukurannya cukup luas (Environmental Care - Green Living, 2014).

Desa Darawa merupakan satusatunya desa yang berada di daratan terpencil pulau Darawa dan merupakan sebuah wilayah Desa administratif dari Kecamatan Kaledupa Selatan, Kabupaten Wakatobi, dengan total 220 Kepala Keluarga dan terdiri dari 3 dusun yaitu dusun Darawa, dusun Horuso, dan dusun Watukoila. Masyarakat di Desa Darawa umumnya berprofesi sebagai nelayan dan petani. Sumber air bagi pemenuhan kebutuhan sehari-hari penduduk Desa Darawa berasal dari air hujan, hal ini dikarenakan kondisi fisik pulau Darawa yang tidak memiliki sumber air tawar.

Air yang baik untuk digunakan harus bebas dari kuman penyebab penyakit dan tidak mengandung bahan beracun, akan tetapi masyarakat Desa Darawa menggunakan air hujan sebagai sumber air minum yang mana kualitas airnya belum terjamin. Oleh karena itu melalui penelitian ini akan dilakukan analisis kualitas fisika kimia air hujan sebagai sumber air minum masyarakat di Desa Darawa, Kecamatan Kaledupa Selatan, Kabupaten Wakatobi.

Tujuan dari penelitian ini adalah (1) Mengetahuikualitas fisik air hujan dalam wadah penampungan warga di Desa Darawa, berdasarkan Standar Kualitas Air Bersih Di Kecamatan Kaledupa Selatan, Kabupaten Wakatobi; (2) Mengetahui kualitas kimia air hujan dalam wadah penampungan warga di Desa Darawa, berdasarkan Standar Kualitas Air Bersih Di Kecamatan Kaledupa Selatan, Kabupaten Wakatobi.

Air merupakan senyawa kimia yang sangat penting bagi kehidupan makhluk hidup di bumi ini. Fungsi air bagi kehidupan tidak 
dapat digantikan oleh senyawa lain. Penggunaan air yang utama dan sangat vital bagi kehidupan adalah sebagai air minum. Hal ini untuk memenuhi kebutuhan air dalam tubuh. Sekitar 55-60\% berat badan orang dewasa terdiri dari air, untuk anak-anak sekitar $65 \%$ dan untuk bayi sekitar $80 \%$ (Notoadmodjo, 2003).

Dalam keputusan Presiden RI No. $81 \quad$ Tahun 2001 TentangKomiteKebijakan PercepatanPembangunanInfrastruktu r, disebut dalam pasal 2, bahwa pembangunan infrastruktur mencakup prasarana dan sarana pengairan serta fasilitas umum yaitu jaringan listrik, telekomunikasi, dan jaringan pipa PAM. Pada standar pelayanan minimal (SPM) bidang air bersih bahwa kewajiban pemerintah berdasarkan target Millennium Development Goals (MDGs) adalah menyediakan air bersih secara kontinyu yang dapat diakses paling tidak oleh $68.87 \%$ penduduk.

UNEP (United Nations Environment Programme) tahun 2011 menyarankan dengan mendasarkan pada meteorologi dan karakteristik geografis pemanenan air hujan, dimana curah hujan tahunan di Indonesia mencapai 2263 $\mathrm{mm}$ yang cenderung terdistribusi secara merata sepanjang tahun tanpa ada perbedaan yang mencolok antara musim hujan dan musim kemarau (Song et al., 2009).

Manfaat air di dalam tubuh manusia antara lain untuk melarutkan berbagai jenis zat yang diperlukan tubuh, mempertahankan suhu tubuh dengan cara penguapan keringat, untuk transportasi zat-zat makanan dalam tubuh semuanya dalam bentuk larutan dengan pelarut air. Sehingga dapat disimpulkan bahwa air sangat memegang peranan penting dalam aktivitas manusia (Slamet, 2007).

\section{METODE PENELITIAN}

\begin{tabular}{lcrr}
\multicolumn{2}{c}{ Penelitian } & ini & telah \\
dilaksanakan & di Desa & Darawa, \\
Kecamatan & Kaledupa & Selatan, \\
Kabupaten & Wakatobi pada & bulan \\
Maret 2018. & &
\end{tabular}

Jenis penelitian ini adalah jenis penelitian kualitatif deskriptifuntuk melihat kualitas air hujan sebagai pemenuhan kebutuhan masyarakat Di Desa Darawa berdasarkan standar kualitas air bersih Kecamatan Kaledupa Selatan, Kabupaten Wakatobi.

Populasi dalam penelitian ini adalah air hujan dalam bak penampungan penduduk desa Darawa yang memanfaatkan air hujan sebagai pemenuhan kebutuhan rumah tangga sehari-hari, yaitu sebanyak 239 KK.

Sampel yang dipilih harus memiliki ciri-ciri dan karakteristik yang memiliki kesamaan dengan keseluruhan populasi sehingga bisa mewakili keseluruhan populasi. Total seluruhnya sampel yang diambil dari lokasi adalah 4 (empat) botol sampel air. Pengambilan sampel airnya diambil secara langsung dari 4 wadah penampungan yang dipilih secara acak dari 4 lokasi berbeda. Parameter kimia pengambilan sampel masing - masing 1 liter air dimasukkan dalam botol yang sebelumnya telah dibersihkan dan dibilas dengan air suling terlebih dahulu, kemudian dikeringkan. Selanjutnya, 4(empat) botol sampel yang telah terisi air tadi dimasukkan dalam gabus pendingin yang telah disediakan agar tidak terjadi perubahan fisika-kimia pada air yang 
akan dibawa dari lokasi sampling ke BalaiLaboratorium Kesehatan Kendari untuk dilakukan pemeriksaansampel..

Dalam usaha untuk pengumpulan data dalam penelitian ini, penulis menggunakan cara sebagai berikut:

1. Teknik Kepustakaan

2. Penelitian Lapangan terdiri dari pengukuran suhu, pengukuran wadah penampungan air, pengambilan sampel dan dokumentasi

Data yang dibutuhkan dapat diperoleh melalui uji laboratorium. Uji laboratorium merupakan metode pengumpulan data yang menggunakan hasil pemeriksaan laboratorium, dimana peneliti mengambil sampel dari lokasi peelitian kemudian dibawa ke Balai Laboratorium Kesehatan Kendari untuk dilakukan pemeriksaan kondisi fisika-kimia sampel air hujan dari Desa Darawa. Adapun sampel yang di uji adalah bau, rasa, warna, kekeruhan, $\mathrm{pH}$, seng ( $\mathrm{Zn})$, Detergen, dan TDS.

Adapun alat dan bahan dalam penelitian ini adalah sebagai berikut :

Tabel 2.1 Alat dan bahan

\begin{tabular}{lll}
\hline No & \multicolumn{1}{c}{ Alat dan bahan } & \multicolumn{1}{c}{ Fungsi } \\
\hline 1 & Alat Tulis & $\begin{array}{l}\text { Untuk mencatat, catatan tersebut berupa catatan } \\
\text { dilapangan }\end{array}$ \\
\hline 2 & Label & Untuk menandai sampel \\
\hline 3 & Botol Aquades & Untuk menyimpan sampel \\
\hline 4 & Gabus Pendingin & Untuk mengawetkan sampel \\
\hline 5 & Hp & Alat dokumentasi \\
\hline 6 & Air sampel yang diambil & Sebagai bahan yang akan diamati \\
\hline 7 & Mari lokasi penelitian & \\
\hline 8 & Gps & Untuk mengukur volume bak penampungan \\
\hline 9 & Thermometer & $\begin{array}{l}\text { Untuk menentukan koordinat pengambilan } \\
\text { sampel }\end{array}$ \\
\hline 10 & $\begin{array}{l}\text { Data sekunder } \\
\text { instansi tetkait }\end{array}$ & Unutk megukur suhu air dilapangan \\
\hline
\end{tabular}

\section{Sumber : Data Diolah (2018)}

Teknik analisis data yang digunakan dalam penelitian ini adalah analisis data komparatif. Analisis data komparatif yaitu metode yang digunakan untuk membandingkan antara kualitas air hujan yang ada dalam wadah penampungan warga di Desa Darawa dari hasil pengukuran dilapangan dan hasil pemeriksaan di laboratorium dengan Peraturan Menteri Kesehatan RI No 492/Per/IV/2010 tentang persyaratan kualitas air minum. 
Tabel 2.2 Peraturan Menteri Kesehatan RI No 492/Per/IV/2010 Tentang Persyaratan Kualitas Air Minum

No Jenis parameter Satuan \begin{tabular}{c}
$\begin{array}{c}\text { maksimum } \\
\text { yang } \\
\text { diperbolehkan }\end{array}$ \\
\hline
\end{tabular}

$1 \quad$ Parameter yang berhubungan langsung dengan kesehatan

\begin{tabular}{cllc}
\hline a. & Parameter mikrobiologi & & \\
\hline b. & E. Coli & $\begin{array}{l}\text { Jumlah per 100 } \\
\text { ml sampel }\end{array}$ & 0 \\
\hline c. & Total bakteri koliform & $\begin{array}{l}\text { Jumlah per 100 } \\
\text { ml sampel }\end{array}$ & 0 \\
\hline d. & Kimia anorganik & & 0,01 \\
\hline e. & Arsen & $\mathrm{Mg} / \mathrm{l}$ & 1,5 \\
\hline f. & Fluorida & $\mathrm{Mg} / \mathrm{l}$ & 0,05 \\
\hline g. & total kromium & $\mathrm{Mg} / \mathrm{l}$ & 0,003 \\
\hline h. & cadmium & $\mathrm{Mg} / \mathrm{l}$ & 3 \\
\hline i. & nitrit & $\mathrm{Mg} / \mathrm{l}$ & 50 \\
\hline j. & nitrat & $\mathrm{Mg} / \mathrm{l}$ & 0,07 \\
\hline k. & sianida & $\mathrm{Mg} / \mathrm{l}$ & 0,01 \\
\hline l. & selenium & $\mathrm{Mg} / \mathrm{l}$ & \\
\hline Parameter yang tidak berhubungan & & \\
langsung dengan kesehatan & & \\
\hline
\end{tabular}

a. parameter fisik

\begin{tabular}{cccc}
\hline & & & Tidak berbau \\
\hline$\checkmark$ & warna & $\mathrm{Tcu}$ & 15 \\
\hline$\checkmark$ & tsd & $\mathrm{Ntu}$ & 500 \\
\hline$\checkmark$ & kekeruhan & & 5 \\
\hline$\checkmark$ & rasa & $0 \mathrm{C}$ & $24^{0} \mathrm{C}-30^{\circ} \mathrm{C}$ \\
\hline$\checkmark$ & suhu & & \\
\hline b. & parameter kimia & $\mathrm{Mg} / \mathrm{l}$ & 0,2 \\
\hline$\checkmark$ & aliminium & $\mathrm{Mg} / \mathrm{l}$ & 0,3 \\
\hline$\checkmark$ & besi & $\mathrm{Mg} / 1$ & 500 \\
\hline$\checkmark$ & kesadahan & $\mathrm{Mg} / \mathrm{l}$ & 250 \\
\hline$\checkmark$ & khlorida & $\mathrm{Mg} / \mathrm{l}$ & 0,4 \\
\hline$\checkmark$ & mangan & $\mathrm{Mg} / \mathrm{l}$ & $6,5-8,5$ \\
\hline$\checkmark$ & ph & $\mathrm{Mg} / \mathrm{l}$ & 3 \\
\hline$\checkmark$ & seng & $\mathrm{Mg} / \mathrm{l}$ & 250 \\
\hline$\checkmark$ & sulfat & $\mathrm{Mg} / \mathrm{l}$ & 2 \\
\hline$\checkmark$ & tembaga & $\mathrm{Mg} / \mathrm{l}$ & 1,5 \\
\hline$\checkmark$ & ammonia & & \\
\hline $\mathrm{c}$. & parameter tambahan kimiawi & & 0,001 \\
\hline$\checkmark$ & bahan anorganik & $\mathrm{Mg} / \mathrm{l}$ & 0,02
\end{tabular}




\begin{tabular}{clcc}
\hline No & Jenis parameter & Satuan & $\begin{array}{c}\text { Kadar } \\
\text { maksimum } \\
\text { yang } \\
\text { diperbolehkan }\end{array}$ \\
\hline$\checkmark$ & Barium & $\mathrm{Mg} / \mathrm{l}$ & 0,7 \\
\hline$\checkmark$ & Boron & $\mathrm{Mg} / \mathrm{l}$ & 0.5 \\
\hline$\checkmark$ & Molibdenum & $\mathrm{Mg} / \mathrm{l}$ & 0,07 \\
\hline$\checkmark$ & Nikel & $\mathrm{Mg} / \mathrm{l}$ & 0,07 \\
\hline$\checkmark$ & Sodium & $\mathrm{Mg} / \mathrm{l}$ & 200 \\
\hline$\checkmark$ & Timbal & $\mathrm{Mg} / \mathrm{l}$ & 0,01 \\
\hline$\checkmark$ & Uranium & $\mathrm{Mg} / \mathrm{l}$ & 0,015 \\
\hline $\mathrm{d}$. & Bahan organic & & \\
\hline$\checkmark$ & Zat organic & $\mathrm{Mg} / \mathrm{l}$ & 10 \\
\hline$\checkmark$ & Deterjen & $\mathrm{Mg} / \mathrm{l}$ & 0,05 \\
\hline
\end{tabular}

Sumber : Peraturan Menteri Kesehatan RI No 492/Per/IV/2010 tentang persyaratan kualitas air minum

\section{HASIL PENELITIAN}

Data hasil pengukuran sampel secara langsung dilapangan untuk parameter suhu dan $\mathrm{pH}$ serta titik koordinat pengambilan sampel dapat dilihat pada gambar dan tabel berikut:

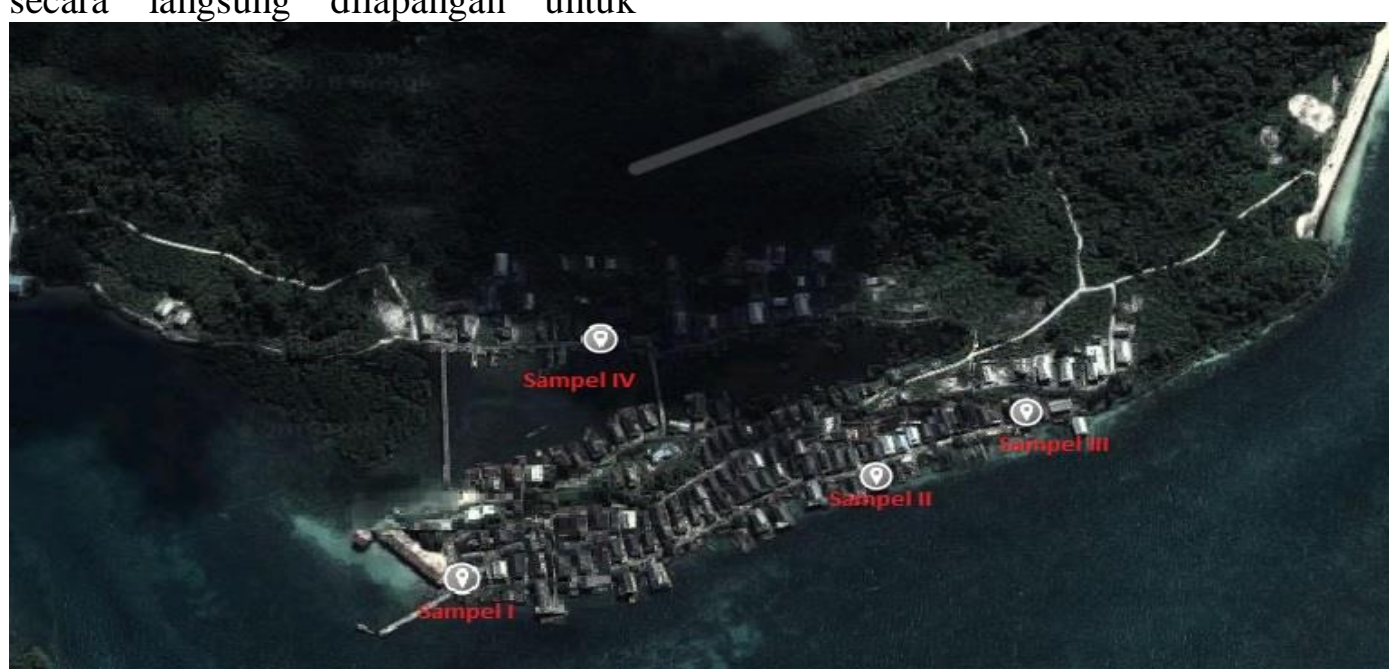

Gambar 3.1.Peta titik sampel penelitian

Tabel 3.1 Data Hasil Pengukuran Langsung di Lapangan

\begin{tabular}{|c|c|c|c|c|}
\hline $\begin{array}{c}\text { No } \\
\text { Sampel }\end{array}$ & Nama Dusun & Titik koordinat sampel & $\mathrm{pH}$ & Suhu \\
\hline 1 & $\begin{array}{c}\text { Dusun } \\
\text { Watukoila }\end{array}$ & 5033'25.758'S 12351'37.979’"E & 8.12 & $26,12^{\circ} \mathrm{C}$ \\
\hline 2 & $\begin{array}{c}\text { Dusun } \\
\text { Watukoila }\end{array}$ & 5033'28.429”S 12351'43.672”E & 8.31 & $26,8^{\circ} \mathrm{C}$ \\
\hline 3 & Dusun Darawa & 5033'28.277'S 12351'43.611'E & 8,32 & $26,10^{\circ} \mathrm{C}$ \\
\hline 4 & Dusun Horuso & 5033'32.970”'S12351'31.211'"E & 8,20 & $26,05^{\circ} \mathrm{C}$ \\
\hline
\end{tabular}

Sumber : Data diolah (2018) 
Data hasil pemeriksaan sampel laboratorium untuk parameter Fisik dan Kimia dapat dilihat pada table berikut:

Tabel 3.2 Hasil Uji Laboratorium Terhadap Sampel Air Hujan di Desa Darawa, Kecamatankaledupa Selatan, Kabupaten Wakatobi.

\begin{tabular}{|c|c|c|c|c|c|c|c|}
\hline \multirow{2}{*}{ No } & \multirow{2}{*}{ Parameter } & \multirow{2}{*}{ Satuan } & \multirow{2}{*}{$\begin{array}{c}\text { Peraturan } \\
\text { Menkes } \\
\text { RI No } \\
\text { 49/Menkes/ } \\
\text { Per/IV/2010 }\end{array}$} & \multicolumn{4}{|c|}{ Hasil pengukuran } \\
\hline & & & & $\begin{array}{c}\text { Sampel } \\
1\end{array}$ & $\begin{array}{c}\text { Sampel } \\
2\end{array}$ & $\begin{array}{c}\text { Sampel } \\
3\end{array}$ & $\begin{array}{c}\text { Sampel } \\
4\end{array}$ \\
\hline A & Fisik & & & & & & \\
\hline 1 & Suhu & ${ }^{\circ} \mathrm{C}$ & $23-30$ & 26,08 & 26,12 & 26,10 & 26,05 \\
\hline 2 & Bau & & Tidak berbau & $\begin{array}{l}\text { Tidak } \\
\text { berbau }\end{array}$ & $\begin{array}{c}\text { Tidak } \\
\text { berbau }\end{array}$ & $\begin{array}{c}\text { Tidak } \\
\text { berbau }\end{array}$ & $\begin{array}{l}\text { Tidak } \\
\text { berbau }\end{array}$ \\
\hline 3 & Rasa & & Tidak berasa & $\begin{array}{c}\text { Tidak } \\
\text { berasa }\end{array}$ & $\begin{array}{c}\text { Tidak } \\
\text { berasa }\end{array}$ & $\begin{array}{l}\text { Tidak } \\
\text { berasa }\end{array}$ & $\begin{array}{l}\text { Tidak } \\
\text { berasa }\end{array}$ \\
\hline 4 & $\begin{array}{c}\text { Kekeruha } \\
n\end{array}$ & NTU & 5 & 0,33 & 0,35 & 0,31 & 0,27 \\
\hline 5 & Warna & & 15 & 10 & 10 & 10 & 10 \\
\hline 6 & TDS & $\mathrm{mg} / \mathrm{L}$ & 500 & 322 & 354 & 324 & 328 \\
\hline $\mathrm{B}$ & Kimia & & & & & & \\
\hline 7 & $\mathrm{pH}$ & $\mathrm{mg} / \mathrm{L}$ & $6,5-8,5$ & 8,12 & 8,31 & 8,34 & 8,24 \\
\hline 8 & Seng $(\mathrm{Zn})$ & $\mathrm{mg} / \mathrm{L}$ & 3 & 0,0782 & 0,0812 & 0,0850 & 0,0762 \\
\hline 9 & Deterjen & $\mathrm{mg} / \mathrm{l}$ & 0,05 & 0,03 & 0,02 & 0,03 & 0,02 \\
\hline
\end{tabular}

Sumber :Data diolah (2018)

Berdasarkan hasil Analisa laboratorium yang telah dikeluarkan oleh Balai Laboratorium Kesehatan Kendari, dari masing-masing parameter yang diteliti pada empat sampel air hujan yang diambil dari lokasi penelitian tidak terdapat nilai yang melampaui ambang batas maksimum yang diperbolehkan oleh Peraturan Menteri Kesehatan RI No. 492/ Menkes/ Per/ IV/ 2010 tentang persyaratan kualitas air minum. Jadi dapat disimpulkan bahwa berdasarkan beberapa parameter yang diuji dari air hujan yang ditampung dalam bak penampungan warga di Desa Darawa masih di bawah baku mutu kualitas air minum yang dipersyaratkan menurut Permenkes No. 492/ Menkes/ Per/ IV/ 2010.

\section{a. Analisa Univariat}

\section{Gambaran Kualitas Fisik Air Hujan}

Hasil penelitian mengenai parameter air hujan secara fisik dalam wadah penampungan masyarakat di Desa Darawa terdiri dari parameter suhu, bau, rasa, kekeruhan dan warna, dapat dilihat pada tabel berikut : 
Tabel 3.3 KualitasFisik Air Hujan Dalam Wadah Penampungan Milik Warga di Desa Darawa, Kec. Kaledupa Selatan, Kab. Wakatobi.

\begin{tabular}{ccccc}
\hline $\begin{array}{c}\text { Parameter } \\
\text { fisik air hujan }\end{array}$ & \multicolumn{2}{c}{ Memenuhi syarat } & \multicolumn{2}{c}{ Tidak memenuhi syarat } \\
\hline & Frekuensi & Persentase & frekuensi & Persentase \\
\hline Suhu & 4 & $100 \%$ & 0 & $0 \%$ \\
\hline Bau & 4 & $100 \%$ & 0 & $0 \%$ \\
\hline Rasa & 4 & $100 \%$ & 0 & $0 \%$ \\
\hline Kekeruhan & 4 & $100 \%$ & 0 & $0 \%$ \\
\hline Warna & 4 & $100 \%$ & 0 & $0 \%$ \\
\hline TDS & 4 & $100 \%$ & 0 & $0 \%$ \\
\hline
\end{tabular}

\section{Sumber : Data Diolah (2018)}

2. Gambaran Kualitas Kimia Air Hujan

Adapun hasil analisis laboratorium yang dikeluarkan oleh Balai Laboratorium Kesehatan Kendari mengenai gambaran air hujan

Tabel 3.4 Kualitas kimia air hujan dalam wadah penampungan milik warga di Desa Darawa, Kec. Kaledupa Selatan, Kab. Wakatobi.

\begin{tabular}{ccccc}
\hline $\begin{array}{c}\text { Parameter } \\
\text { kimia air } \\
\text { hujan }\end{array}$ & Memenuhi syarat & Tidak memenuhi syarat \\
\hline $\mathrm{pH}$ & Frekuensi & Persentase & Frekuensi & Persentase \\
\hline Seng(Zn) & 4 & $100 \%$ & 0 & $0 \%$ \\
\hline Detargen & 4 & $100 \%$ & 0 & $0 \%$ \\
\hline
\end{tabular}

\section{Sumber: Data diolah (2018)}

\section{PEMBAHASAN}

Berdasarkan hasil analisis laboratorium yang telah dikeluarkan oleh Balai Laboratorium Kesehatan Kendari pada tanggal 16 Maret 2018, hasil penelitian kualitas air hujan tersebut dibagi dalam beberapa karakteristik pengujian. Adapun karakteristik yang menjadi objek penelitian tersebut terdiri dari parameter fisik dan parameter kimia.

- Hasil pengukuran suhu air yang dilakukan langsung dilapangan dengan menggunakan thermometer aquarium menunjukkan suhu air rata- dalam wadah penampungan warga di Desa Darawa yang ditinjau secara kimia yakni terdiri dari parameter $\mathrm{pH}$, Seng (Zn) dan Deterjen, dapat dilihat pada table berikut: 
warna air hujan pada semua sampel yang diambil dari empat titik lokasi yang berbeda rata-rata angka kadar yang diperoleh, baik pada sampel I, sampel II, sampel III, maupun sampel IV, yaitu sebesar 10TCU dan memenuhi syarat Peraturan Menteri Kesehatan RI No. 492/ Menkes/ Per/ IV/ 2010 yaitu 15 TCU.

Hasil penggujian sampel air pada parameter rasa dengan meminta kepada empat responden untuk memberikan penilaian terhadap sampel I, sampel II, sampel, III, dan sampel IV yaitu dengan cara memasukkan air kedalam botol sampel kemudian meminta kepada empat orang responden untuk menanggapi rasa dari masing-masing sampel air, dari keenam responden semuanya menyatakan bahwa sampel air tidak berasa. Sehinggga kesimpulannya air dalam wadah penampunga warga tidak berasa dan memenuhi syarat Peraturan Menteri Kesehatan RI No. 492/ Menkes/ Per/ IV/ 2010 yaitu tidak berasa.

Hasil uji laboratorium terhadap parameter bau dari aroma yang ditimbulkan baik oleh sampel I, sampel II, sampel III, maupun pada sampel IV tidak berbau dan memenuhi syarat Peraturan Menteri Kesehatan RI No. 492/ Menkes/ Per/ IV/ 2010 yaitu tidak berbau.

Berdasarkan syarat Peraturan

Menteri Kesehatan RI No. 492/ Menkes/ Per/ IV/ 2010 maksimum adalah 5 NTU. Kekeruhan yang tercatat pada air hujan dalam sampel I (0,33 NTU), sampel II $(0,5)$,sampel III $(0,31)$ dan sampel IV $(0,27)$, sehingga jika ditinjau dari parameter kekeruhan tingkat kekeruhan air hujan dalam wadah penampungan warga berada di bawah batas angka yang diperbolehkan berdasarkan Peraturan Menteri Kesehatan RI No. 492/
Menkes/ Per/ IV/ 2010, dan layak untuk dikonsumsi.

Berdasarkan hasil pemeriksaan sampel yang dikeluarkan oleh Balai Laboratorium Kesehatan Kendari meski terbilang cukup tinggi yaitu pada sampel I sebesar 322, sampel II sebesar 354, sampel III sebesar 325 dan pada sampel IV sebesar 324 akan tetapi kadar Total Padatan Terlarut (TDS) yang terkandung dalam air hujan layak untuk dikonsumsi berdasarkan syarat Peraturan Menteri Kesehatan RI No. 492/ Menkes/ Per/ IV/ 2010 yaitu maksimal $500 \mathrm{mg} / \mathrm{l}$ kadar TDS yang diperbolehkan.

Hasil penelitian menunjukkan bahwa nilai $\mathrm{pH}$ pada masing-masing sampel berkisar antara sampel I sebesar 8,12, sampel II sebesar 8,31, sampel III sebesar 8,34 dan sampel IV memiliki $\mathrm{pH}$ sebesar 8,32. Kadar $\mathrm{pH}$ yang terbilang tinggi biasanya disebabkan oleh beberapa kondisi, diantaranya : letak pemukiman yang terlalu dekat dengan laut dan penampungan air hujan dalam bak penampungan dalam waktu yang cukup lama. Namun demikian, kadar $\mathrm{pH}$ air hujan yang digunakan oleh masyarakat di Desa Darawa masih berada di bawah angka yang ditetapkan Peraturan Menteri Kesehatan RI No. 492/ Menkes/ Per/ IV/ 2010 yaitu $\mathrm{pH}$ maksimal air yang diperbolehkan adalah 6,5-8,5.

$$
\text { Hasil Analisa yang }
$$

dikeluarkan oleh laboratorium diperoleh angka kadar Seng (Zn) pada sampel air I 0,0728, pada sampel II 0,0812 , sampel III 0,0850 dan pada sampel IV sebesar 0,0762 mg/l. Jika ditinjau dari kadar kandungan Seng (Zn) sampel air hujan dari Desa Darawa layak untuk dikonsumsi karena masih berada jauh dibawah baku mutu kualitas air yang ditetapkan oleh Peraturan Menteri Kesehatan RI 
No. 492/ Menkes/ Per/ IV/ 2010 yaitu $3 \mathrm{mg} / \mathrm{l}$.

Berdasarkan hasil analisis laboratorium kadar detergen yang terkandung dalam sampel I sebesar 0,03 , sampel II 0,02 sampel III 0,03 dan sampel IV sebesar $0,02 \mathrm{mg} / \mathrm{l}$. Angka-angka tersebut masih berada dibawah baku mutu kualiatas air yang ditetapkan oleh Peraturan Menteri Kesehatan RI No. 492/ Menkes/ Per/ IV/ 2010 yaitu kadar detergen yang diperbolehkan untuk dikonsumsi tidak lebih dari 0,05 mg/l.

Kesimpulan dari hasil pemeriksaan laboratorium sebagaimana yang tercantum pada table 4.3 menunjukka bahwa air hujan di Desa Darawa ditinjau secara kimia pada beberapa parameter yakni parameter $\mathrm{pH}$, Detergen dan Seng (Zn), dapat disimpulkan bahwa diantara parameter yang diuji, baik parameter $\mathrm{pH}$, parameter Detergen dan parameter Seng ( $\mathrm{Zn})$, masing-masing memenuhi syarat $100 \%$ karena semua sampel menunjukkan angka dibawah baku mutu kandungan kadar Detergen dan Seng ( $\mathrm{Zn})$ yang diperbolehkan sebagaimana yang tertera dalam Peraturan Menteri Kesehatan RI No. 492/ Menkes/ Per/ IV/ 2010 tentang persyaratan kualitas air minum. Begitu juga dengan hasil uji laboratorium maupun pemeriksaan lansung di lapangan terhadap aspek fisika yang terdiri dari parameter suhu, bau, rasa, warna, kekeruhan, dan TDS. Masingmasing parameter menunjukkan angka yang layak berdasarkan Peraturan Menteri Kesehatan RI No. 492/ Menkes/ Per/ IV/ 2010.

\section{Implikasi Terhadap Kurikulum Pendidikan di Sekolah}

Sesuai dengan judul penelitian dan pembahasan dalam penelitian ini, hasil dari penelitian ini dapat dijadikan sebagai kontribusi bagi para guru maupun siswa sebagai bahan pelajaran dalam mata pelajaran Geografi pada kelas X (sepuluh) pada semester II, materi pokok Siklus Hidrologi dan Pemanfaatan Dalam Kehidupan Sehari-hari (kurikulum 2013), dengan alokasi waktu 2 x 15 menit. Dalam pembahasannya mencakup beberapa pokok bahasan yaitu Mendeskripsikan karakteristik perairan darat dan pengaruhnya bagi kehidupan, menjelaskan proses terjadinya hujan, klasifikasi hujan dan menghitung rerata curah hujan.

Dalam pokok pembahasan tersebut menjelaskan bagaimana hidrosfer merupakan bagian dari kajian ilmu geografi, hidrosfer atau lapisan air yang ada dipemukaan bumi menjadi salah satu objek yang dikaji dalam fokus ilmu geografi. Hidrosfer adalah perairan yang mengelilingi bumi dan tak bisa dipisahkan dalam proses pembentukan hujan berupa samudera, laut, sungai, danau, gletser, air tanah, mata air, dan sebagainya.

\section{KESIMPULAN}

Berdasarkan hasil penelitian yang telah dilakukan, maka dapat ditarik kesimpulan sebagai berikut :

1. Kualitas air hujan dalam bak penampungan warga dilihat dari 6 (enam) parameter fisik, yaitu : parameter suhu, parameter warna, parameter bau, parameter rasa, parameter kekeruhan dan TDS, semua parameter tersebut memenuhi syarat dan layak untuk dikonsumsi menurut Peraturan Menteri Kesehatan RI No. 492/ Menkes/ Per/ IV/ 2010 tentang persyaratan kualitas air minum.

2. Kualitas air hujan dalam bak penampungan warga dilihat dari 3 (tiga) parameter kimia, yaitu: 
parameter $\mathrm{pH}, \quad$ parameter Detergen dan parameter Seng (Zn) masing-masing memenuhi $100 \%$ syarat untuk dikonsumsi karena masih berada di bawah kadar yang ditentukan oleh Peraturan Menteri Kesehatan RI No. 492/ Menkes/ Per/ IV/ 2010 tentang persyaratan kualitas air minum.

\section{DAFTAR PUSTAKA}

Seyhan, Ersin. 1995. Dasar-Dasar Hidrologi. Yogyakarta: Gadjah Mada University Press.

Harudu, La, \& Desi Nurul Hidayati. 2017. Bahan Ajar Hidrologi. Kendari: Universitas Halu Oleo

Margono. 1997. Penelitian kualitatif. Yokyakarta: Rineka Cipta

Seyhan Ersin. 1990. Dasar-dasar Hidrologi. Yogyakarta: Gadjah mada University Press.

Suriawiria 2002. Teknologi Penyediaan Air Bersih. Jakarta: Rineka Cipta.

Wulan, Trimurti, Sukia. 2016. Analisis Kualitas Air Sumur Masyarakat Kelurahan Lalohara Ke. Kambu. Kendari : Universitas Halu Oleo. 